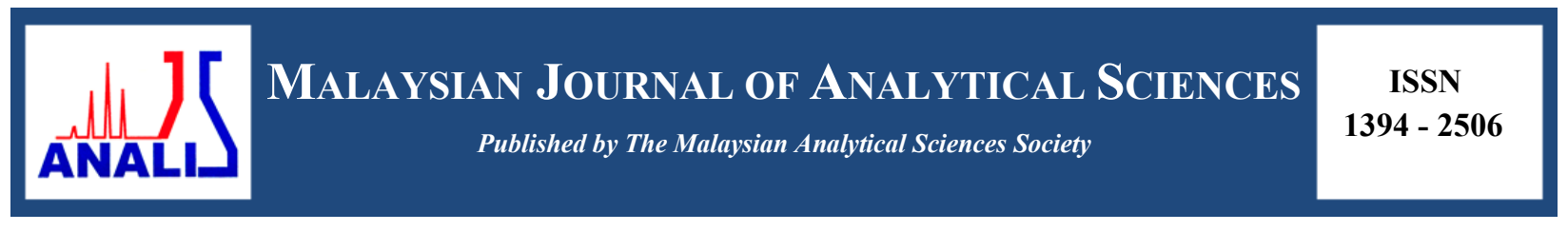

\title{
ALGAE OIL EXTRACTION FROM FRESHWATER MICROALGAE Chlorella vulgaris
}

\author{
(Pengekstrakan Minyak Alga Daripada Mikroalga Air Tawar Chlorella vulgaris) \\ Nurfarahanim Abdullah, Nur Amelia Amran, Nur Hidayah Mat Yasin* \\ Faculty of Chemical Engineering \& Natural Resources, \\ Universiti Malaysia Pahang, 26300 Gambang, Pahang, Malaysia \\ *Corresponding author: hidayahyassin@ump.edu.my
}

Received: 28 November 2016; Accepted: 5 February 2017

\begin{abstract}
This research aims to investigate the optimum condition of oil extraction method to extract maximum oil yield from freshwater microalgae Chlorella vulgaris. The modified soxhlet extraction method was used to identify the best solvent systems which are heptane, heptane: methanol (1:1), heptane: methanol (1:2), heptane: ethanol (1:1) and heptane: ethanol (1:2) for extracting the microalgae oil. The effect of different mixing rate $(\mathrm{rpm})$, temperature $\left({ }^{\circ} \mathrm{C}\right)$ and extraction time (hours) were carried out using the optimized solvent system to evaluate the optimum condition of oil extraction. Based on the yield of oil extraction, heptane alone become the best solvent to extract the oil with the yield of $57.5 \%$, followed by heptane: methanol (1:2), heptane: ethanol (1:1), heptane: ethanol (1:2) and heptane: methanol (1:1) with the yield of 47.5\%, 44.8\%, 43.2\% and 41.4\%, respectively. Maximum oil quantity of $61.27 \%$ was obtained after extracted the Chlorella vulgaris biomass using heptane as a solvent at the following optimal conditions: mixing rate of $600 \mathrm{rpm}$, temperature of $65^{\circ} \mathrm{C}$ and extraction time of 5 hours. This study confirmed that an increasing temperature resulted in the increased of oil yield, but at higher temperature (greater than $65^{\circ} \mathrm{C}$ ), the oil yield was decreasing. Too high of temperature in oil extraction may cause partial decomposition of the microalgae cells and thus lowering the yield of oil extracted.
\end{abstract}

Keywords: soxhlet extraction, oil extraction, freshwater microalgae, Chlorella vulgaris, solvent systems

\begin{abstract}
Abstrak
Kajian ini bertujuan untuk mengkaji keadaan optimum bagi kaedah pengekstrakan minyak dalam usaha untuk mendapatkan hasil minyak maksimum daripada mikroalga air tawar Chlorella vulgaris. Kaedah pengekstrakan soxhlet yang diubah suai digunakan untuk mengenal pasti sistem pelarut yang terbaik iaitu heptana, heptana: metanol (1:1), heptana: metanol (1:2), heptana: etanol (1:1) dan heptana: etanol (1:2) untuk mengekstrak minyak mikroalga. Kesan daripada kadar pencampuran yang berbeza (rpm), suhu $\left({ }^{\circ} \mathrm{C}\right)$ dan masa pengekstrakan (jam) telah dijalankan dengan menggunakan sistem pelarut yang telah dioptimumkan untuk menilai keadaan optimum pengekstrakan minyak. Berdasarkan hasil pengeluaran minyak, heptana bersendirian menjadi pelarut terbaik untuk mengeluarkan minyak dengan hasil sebanyak 57.5\%, diikuti oleh heptana: metanol (1:2), heptana: etanol (1:1), heptana: etanol (1:2) dan heptana: metanol (1:1) dengan hasil masing - masing 47.5\%, 44.8\%, 43.2\% dan 41.4\%. Kuantiti minyak maksimum $61.27 \%$ telah diperolehi selepas biojisim Chlorella vulgaris diekstrak menggunakan heptana sebagai pelarut pada keadaan optimum berikut: kadar percampuran $600 \mathrm{rpm}$, suhu $65{ }^{\circ} \mathrm{C}$ dan 5 jam masa pengekstrakan. Kajian ini mengesahkan bahawa suhu meningkat menyebabkan peningkatan hasil minyak, tetapi pada suhu yang lebih tinggi (lebih daripada $65^{\circ} \mathrm{C}$ ), hasil minyak telah berkurangan. Suhu yang terlalu tinggi dalam pengekstrakan minyak boleh menyebabkan penguraian sebahagian daripada sel-sel alga dan seterusnya mengurangkan hasil minyak yang dikeluarkan.
\end{abstract}

Kata kunci: pengekstrakan soxhlet, pengekstrakan minyak, mikroalga air tawar, Chlorella vulgaris, sistem pelarut 


\section{Introduction}

Limitations of fossil fuels have brought the studies of microalgae as the promising raw materials to produce biodiesel. Microalgae appear to be the source of biodiesel production because of the high growth rate without competing for arable land which makes algae an exciting raw material to the sustainable fuel portfolio [1]. Besides, it has the potential to produce more oil as compared to the other raw materials [2] such as rapeseed, soybean, sunflower and palm. Moreover, microalgae biodiesel are non-toxic, highly bio-degradable; contain no sulphur and the left over materials after extracting the oil can be used for ethanol production or as soil fertilizer [3]. In addition, renewable biodiesel produce from microalgae is capable of meeting the global demand for transport fuels and oil productivity of microalgae greatly exceeds the oil productivity of the best producing oil crops such as corns.

Chisti [4] reported that Chlorella sp., Spirulina sp. and Nitzschia sp. are the main microalgae sources that are usually used to produce biodiesel. It is because these three microalgae species produce the highest oil content $(\%$ dry weight) among the other species with $28-32 \%$ oil content produced by Chlorella sp., Spirulina sp. produce $50-$ $77 \%$ oil content and Nitzschia sp. produce about $45-47 \%$ oil content. According to Islam et al. [5], microalgae have received much attention as a new source of renewable energy in the form of biodiesel. However, they are not yet commercially viable because of the high cost of the production process and also limited information available on the parameters affecting extraction of microalgae oil for commercial biodiesel production. For this reason, a vigorous quantification of the extraction parameters is critical to optimize and consequently increase the feasibility of the process.

Oil extraction from algae is a hotly debated topic currently because this process is one of the more costly processes which can determine sustainability of algae-based biodiesel. Various methods to extract the oil from microalgae are available such as expeller/press, solvent extraction and supercritical fluid extraction [2]. Expeller pressing is the method of extracting oil with a mechanical press rather than utilizing a chemical extraction process and this method provides yields of only $65-70 \%$ of the oil [6] while extraction using supercritical fluid gives very high purity and good product concentration but the operating and investment cost is high [7].

Solvent extraction method is a common and efficient technique for producing oil for biodiesel production since it is recovers almost all the oil and leaves behind only $0.5 \%$ to $0.7 \%$ residual oil in the raw material [8] and it is also involves the transfer of a soluble fraction from a solid material to a liquid solvent. In addition, this method has a relatively low operating cost compared with supercritical fluid extraction [9]. However, there are certain disadvantages for solvent extraction method such as poor extraction of polar lipids, long time required for extraction and hazards of boiling solvents [10].

In order to obtain maximum amount of oil extraction by using solvent extraction method, the optimum condition of extraction process for all parameters used in this study must be optimized. Therefore, the following objectives should be achieved in this investigation which are i) to investigate the oil extraction of microalgae biomass using five different solvent systems and ii) to assess the efficiency of solvent extraction method with the use of three different parameters such as mixing rate, temperature and extraction time to obtain maximum oil extraction.

\section{Microalgae}

\section{Materials and Methods}

The microalgae Chlorella vulgaris was used in this research. A microalgal strain C. vulgaris was obtained from Culture Collection of Algae and protozoa (CCAP). C. vulgaris appears to be the best choice and the most suitable algae species for producing biodiesel [11]. It is one of the most attractive microalgae species for oil extraction owing to its fast growth and easy cultivation [12]. Besides, the strain became the most favored by researchers [13] since it have a high lipids content and easily growth in the laboratory.

\section{Media preparation}

The unicellular microalgae $C$. vulgaris were actually cultured in Bold's Basal Medium with 3-fold nitrogen and vitamins (BBM) by adding $20 \mathrm{~mL}$ of (BBM) (I), $12 \mathrm{~mL}$ of BBM (II), and $2 \mathrm{~mL}$ each of BBM (III) and BBM (IV) to $2000 \mathrm{~mL}$ sterilized distilled water (DW). BBM (I) contain the following compounds per $1 \mathrm{~L}$ of $\mathrm{DW}$ : $75.0 \mathrm{~g}$ of $\mathrm{NaNO}_{3}, 2.5 \mathrm{~g}$ of $\mathrm{CaCl}_{2} .2 \mathrm{H}_{2} \mathrm{O}, 7.5 \mathrm{~g}$ of $\mathrm{MgSO}_{4} \cdot 7 \mathrm{H}_{2} \mathrm{O}, 7.5 \mathrm{~g}$ of $\mathrm{K}_{2} \mathrm{HPO}_{4} .3 \mathrm{H}_{2} \mathrm{O}, 17.5 \mathrm{~g}$ of $\mathrm{KH}_{2} \mathrm{PO}_{4}$ and $2.5 \mathrm{~g}$ of NaCl, 
BBM (II) contained the following compounds per litre of DW: $97.0 \mathrm{mg}$ of $\mathrm{FeCl}_{3} .6 \mathrm{H}_{2} \mathrm{O}, 41.0 \mathrm{mg}$ of $\mathrm{MnCl}_{2} .4 \mathrm{H}_{2} \mathrm{O}$, $5.0 \mathrm{mg}$ of $\mathrm{ZnCl}_{2}, 2.0 \mathrm{mg}$ of $\mathrm{CoCl}_{2} \cdot 6 \mathrm{H}_{2} \mathrm{O}$ and $4.0 \mathrm{mg}$ of $\mathrm{Na}_{2} \mathrm{MoO}_{4} \cdot 2 \mathrm{H}_{2} \mathrm{O}$, BBM (III) contains $0.12 \mathrm{~g}$ of vitamin $\mathrm{B}_{1}$ (Thiaminhydrochloride) per $100 \mathrm{~mL} \mathrm{DW}$ and BBM (IV) consists of $0.1 \mathrm{~g}$ of vitamin $\mathrm{B}_{12}$ (Cyanocobalamin) per 100 mL DW.

\section{Preparation of Chlorella vulgaris culture}

The process had been done by using aseptic technique to avoid any contamination towards microalgae and media. The medium and flasks were sterilized in an autoclave, HV-85 (HIRAYAMA, Japan) for 15 minutes at $121^{\circ} \mathrm{C}$. Approximately, $5 \mathrm{~mL}$ of microalgae stock culture was seeded into $2 \mathrm{~L}$ Schott bottle filled with $2 \mathrm{~L}$ of sterilized DW that contained BBM (I-IV) at $25{ }^{\circ} \mathrm{C}$. Two fluorescent lamps were used for continuous lighting and was cultured with continuously aerated for 12 days by bubbling air through it at a constant pressure [13].

\section{Microalgae harvesting}

The C. vulgaris cells were harvested using centrifuge model $5810 \mathrm{R}$ (Eppendorf, Malaysia) at $8000 \mathrm{rpm}$ for 10 minutes. After centrifugation, the clear solution had been discarded and the resulting C. vulgaris biomass was rinsed once with de-ionized water to remove residual nutrients [14].

\section{Microalgae freeze drying}

The extraction was performed on the dry biomass. Therefore, freeze dryer was used to dry the microalgae biomass before the oil extraction was took over. The biomass was dried overnight by using freeze dryer, RP2 V (SGD Serail Argenteuil, France) to measure the cell dry weight [15].

\section{Destruction of microalgae cells}

Freeze-dried samples of $0.05 \mathrm{~g}$ of $C$. vulgaris biomass along with $16.6 \mathrm{~mL} \mathrm{DW}$ were placed into $250 \mathrm{~mL}$ of round bottom flask and then sonicated for 5 minutes to lyse the cells [15].

\section{Oil extraction}

Solvent extraction method by using modified Soxhlet extraction (SE) was used in the oil extraction process. Modified Soxhlet extraction set up mainly consist of the following apparatus: condenser, retort stand, hot plate stirrer, $1 \mathrm{~L}$ beaker, tube and $250 \mathrm{~mL}$ round bottom flask. Approximately $27.2 \mathrm{~mL}$ of solvent systems was used for each $0.05 \mathrm{~g}$ of the freeze-dried microalgae biomass in extraction step. Five different solvent systems were used to extract the oil from the C. vulgaris biomass which are heptane, heptane: methanol (1:1), heptane: methanol (1:2), heptane: ethanol $(1: 1)$ and heptane: ethanol (1:2). The extraction took place about 5 hours to extract oil from microalgae. Magnetic stirrer was used to mix up the biomass with the solvent at mixing rate of $600 \mathrm{rpm}$ and temperature of $65{ }^{\circ} \mathrm{C}$. After 5 hours of extraction, the mixture was then centrifuged at $4000 \mathrm{rpm}$ for 2 minutes and resulted in separation into three layers [15]. The upper layer contains only water, while middle layer was biomass and lowest layer was oil-solvent mixture. The lowest layer was collected and evaporated using rotary evaporator model BUCHI Rotavapor R-200 to obtain the microalgae oil. After that, the extraction was executed in different parameters such as mixing rate, temperature and extraction time to enhance the oil yield from C. vulgaris biomass using the best solvent from previous result. The details of the experiment are summarized in Table 1.

Table 1. Manipulated and constant variables used in each extraction step

\begin{tabular}{lll}
\hline Experiment & Manipulated Variable & Constant Variables \\
\hline 1 & Solvent: & Mixing rate: $600 \mathrm{rpm}$ \\
& Heptane, & Temperature: $65^{\circ} \mathrm{C}$ \\
& Heptane: methanol $(1: 1)$, & Extraction time: 5 hours \\
& Heptane: methanol $(1: 2)$, & \\
& Heptane: ethanol $(1: 1)$, & \\
& Heptane: ethanol $(1: 2)$ & \\
\hline
\end{tabular}


Table 1 (cont'd). Manipulated and constant variables used in each extraction step

\begin{tabular}{|c|c|c|}
\hline Experiment & Manipulated Variable & Constant Variables \\
\hline 2 & $\begin{array}{l}\text { Mixing rate: } \\
500,600 \text {, and } 700 \mathrm{rpm}\end{array}$ & $\begin{array}{l}\text { Temperature: } 65{ }^{0} \mathrm{C} \\
\text { Extraction time: } 4 \text { hours } \\
\text { Solvent }{ }^{\mathrm{a}}\end{array}$ \\
\hline 3 & $\begin{array}{l}\text { Temperature: } \\
55,65 \text {, and } 75{ }^{\circ} \mathrm{C}\end{array}$ & $\begin{array}{l}\text { Solvent }^{\mathrm{a}} \\
\text { Mixing rate } \\
\text { Extraction time: } 4 \text { hours }\end{array}$ \\
\hline 4 & $\begin{array}{l}\text { Extraction time: } \\
4,6 \text {, and } 8 \text { hours }\end{array}$ & $\begin{array}{l}\text { Solvent }^{\mathrm{a}} \\
\text { Mixing rate }^{\mathrm{b}} \\
\text { Temperature }^{\mathrm{c}}\end{array}$ \\
\hline
\end{tabular}

${ }^{\text {a }}$ Best solvent from experiment 1

${ }^{\mathrm{b}}$ Optimum condition of mixing rate from experiment 2

${ }^{\mathrm{c}}$ Optimum condition of temperature from experiment 3

\section{Determination of oil extraction yield}

After extract the oil, the amount of oil extracted using different solvent systems and parameters was determined by using the following equation $1[16]$ :

$$
\text { oil extraction yield }(\%)=\frac{\text { weight of oil extraction }(\mathrm{g})}{\text { weight of microalgae biomass }(\mathrm{g})} \times 100 \%
$$

\section{Effect of solvent systems on oil extraction}

\section{Results and Discussion}

The effect of solvent systems on microalgae oil extraction yield is shown in Table 2. The solvents used for the extraction of microalgae biomass showed the different yields. The highest oil extraction yield of $57.5 \%$ was achieved from Chlorella vulgaris biomass was heptane. Approximately $47.5 \%$ of oil extraction yield was achieved using heptane: methanol $(1: 2)$. Whereas the yield $44.8 \%$ was obtained using heptane: ethanol $(1: 1)$. The oil extraction yield for heptane: methanol (1:1) and heptane: ethanol (1:2) was found to be $41.4 \%$ and $43.2 \%$, respectively.

Table 2. Effect of various solvent systems on oil extraction yield (\%)

\begin{tabular}{lll}
\hline Solvent/Solvent Mixture & Ratio & Oil Extraction (\%) \\
\hline Heptane & - & $57.5 \pm 0.5$ \\
Heptane: Methanol & $1: 1$ & $41.4 \pm 0.5$ \\
Heptane: Methanol & $1: 2$ & $47.5 \pm 1.0$ \\
Heptane: Ethanol & $1: 1$ & $44.8 \pm 0.6$ \\
Heptane: Ethanol & $1: 2$ & $43.2 \pm 1.0$ \\
\hline
\end{tabular}

Figure 1 shows the percentage of oil yield obtained for different solvent systems. The extraction yield increase in the following order: H:M $(1: 1)<\mathrm{H}: \mathrm{E}(1: 2)<\mathrm{H}: \mathrm{E}(1: 1)<\mathrm{H}: \mathrm{M}(1: 2)<\mathrm{H}$. Oil extraction by heptane alone is found to 
be most effective than combination of solvent systems. This observation might be due to the other solvent's physical characteristic distracting the ability of heptane to extract the oil. Therefore, the combination of solvent system between heptane and alcohol are less effective to extract the oil compared to heptane alone.

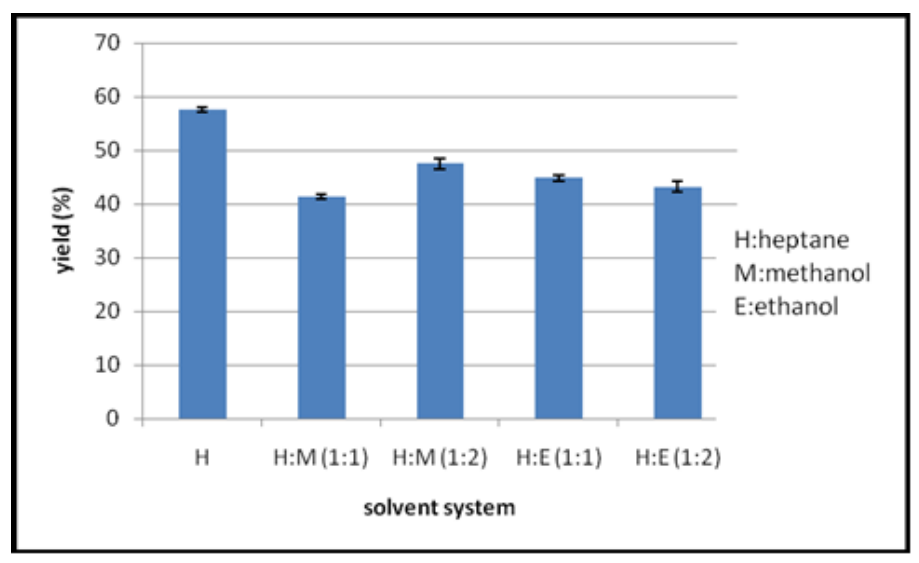

Figure 1. Oil extraction yield with different solvent systems

The selection of the solvent system for oil extraction is an important factor in order to produce the highest yield of oil. Basically, solvent system should have a higher solubility with oil to degrade the cell walls of the microalgae and also to dissolve the oil to enhance the oil yield. However, efficiency of oil extraction yield depends on polarity of the compound and solvent viscosity [17].

The selected solvents were come from two polarity-based classes: polar protic and non-polar. Polar protic solvents usually used to dissolve salt. Generally, these solvents have high dielectric constant and high polarity. The common characteristic of polar protic solvents is hydrogen bond containing hydroxyl group [17] for example water, low molecular weight alcohol such as methanol and ethanol, and the solution that have low molecular-weight carboxylic acid. While, non-polar solvents contain bonds between atoms with similar electronegativities [17] such as carbon and hydrogen. Similar electronegativities mean that small difference between atoms causing less polar bond, thus easier to extract the oil. Alkanes like hexane and heptane are example for this non-polar solvent [18].

Besides, solvent viscosity becomes one of the physical properties that affect the extractability of oil from microalgae. Low-viscosity solvents have a high diffusivity that allows them to easily diffuse into the microalgae biomass to leach out the oil [19].

Based on the research done by Conkerton et al. [20], heptane is the best alternative solvent to replace hexane since the physical properties of heptane is quite similar to hexane which is high stability, low greasy residual and low corrosiveness. Heptane also has a low viscosity and low polarity since it is non-polar group compared to the other solvents. Low viscosity and polarity gave a result of higher yield compare to the other solvent systems.

However, when the heptane is combine with other solvent to extract the oil, the yield of oil extraction become low. This observation is in contrast to the study of Ryckebosch et al. [21] which state that solvent mixture containing a polar and a non-polar solvent could extract a great amount of oil such as a combination of chloroform (non-polar) and methanol (polar). In addition, the result studied by Li et al. [22] also showed a significant difference in extraction efficiency between single and mixture solvent. The oil extraction yield in the mixture was nearly three times higher than when using single solvent.

Despite of these contradict results with Ryckebosch et al. [21] and Li et al. [22], experimental result obtained is similar with Shen et al, [23] where oil recovery was higher in the single solvent. A possible cause for the lower oil 
recovery efficiency in mixture solvent may be that small quantities of oils are took over by polar solvent that cannot be extracted by heptane. Besides, the physical properties of solvent systems such as viscosity and polarity might be change due to the mechanism formed by two different solvents with microalgae cells. The combination of solvents may changes the polarity and viscosity of heptane that have an ability to extract the oil, thus may not help to extract the oil as much as heptane alone can extract. However, the combination of solvent systems between heptane and alcohol still can be used as long as it is implied at appropriate proportions of polar and non-polar solvents in order to achieve high oil extraction yields.

\section{Effect of mixing rate on oil extraction}

The effect of mixing rate on oil extraction is shown in Figure 2. The oil extraction yield in the range of 500 to 700 $\mathrm{rpm}$ was evaluated with constant temperature of $4{ }^{\circ} \mathrm{C}$ and extraction time of 4 hours. The result obtained shows that the oil yield was increasing with the increase in the mixing rate. The oil extraction yield increased from $54.74 \%$ at $500 \mathrm{rpm}$ to $57.86 \%$ at $600 \mathrm{rpm}$. However, at $700 \mathrm{rpm}$, there was no significant increase in the oil yield where $57.94 \%$ of oil can be extracted from C. vulgaris.

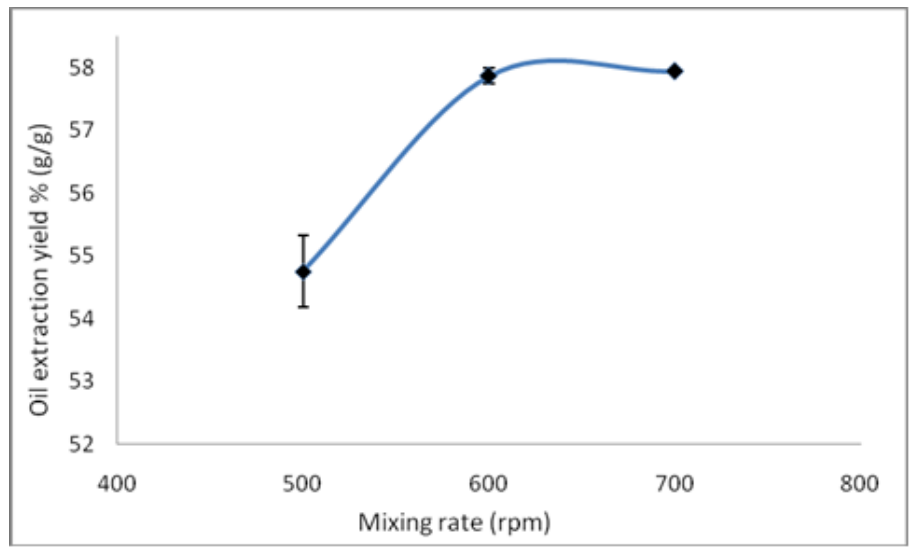

Figure 2. The effect of mixing rate on the oil extraction yield

Mixing rate of the extraction will affects the oil yield of C. vulgarisand it is proving by result obtained in Figure 2 . Increasing mixing rate will increases the eddy diffusion and the transfer of oil from the slurry form of the microalgae biomass to the solvent mixture [24]. The increasing oil yield shows that the mass transfer plays major role during the extraction process. However, at $700 \mathrm{rpm}$, the oil yield becomes constant because the extraction has gone completion at $600 \mathrm{rpm}$ and no further increase in oil extraction yield was observed. Thus, it can be concluded that the maximum oil yield was obtained at $600 \mathrm{rpm}$ which is $57.86 \%$.

Similar phenomenon was also found by Suganya and Renganathan [24] that studied the effect of mixing rate on oil extraction from $U$. lactuca using hexane as a solvent and solvent-to-ratio of 5:1. They have extracted oil from $7.81 \%$ to $9.36 \%$ with the use of mixing rate varying from 200 to $800 \mathrm{rpm}$. Maximum oil yield was achieved at 500 rpm which is $9.36 \%$. Another research by Kadi and Fellag [25] indicated that the oil extraction from olive foot cake using hexane as a solvent have extracted oil from $6.9 \%$ to $7.7 \%$ with the use of mixing rate varying from 600 to $1000 \mathrm{rpm}$ and the maximum yield was obtained at $800 \mathrm{rpm}$ which is $7.7 \%$. Even though the optimum mixing rate for both cases were achieved in the range of 500 to $800 \mathrm{rpm}$, the oil yield obtained from the previous researches is smaller which is between 7.7 to $9.36 \%$ compared to the current study $(57.86 \%)$. The major differences in the oil yield obtained from previous studies and current study is due to the different extraction time used to extract oil from U. lactuca, olive foot cake and C. vulgaris. Oil yield obtained from U. lactuca and olive foot cake were studied for 120 minutes and 10 minutes only, while the extraction time used to obtain the oil yield from C. vulgaris is 4 hours which is longer than the extraction time used in previous studies and eventually more oil is extracted in longer extraction time. 


\section{Effect of temperature on oil extraction}

The effect of temperature on the microalgae oil extraction was investigated over the range of 55 to $75{ }^{\circ} \mathrm{C}$ from $C$. vulgaris biomass (Figure 3). The increase in temperature from 55 to $65{ }^{\circ} \mathrm{C}$ leads to increase in the oil extraction yield from $47.29 \%$ to $56.92 \%$ while increasing the temperature from $65{ }^{\circ} \mathrm{C}$ to $75{ }^{\circ} \mathrm{C}$ resulted in decreasing the oil yield from $56.92 \%$ to $52.26 \%$.

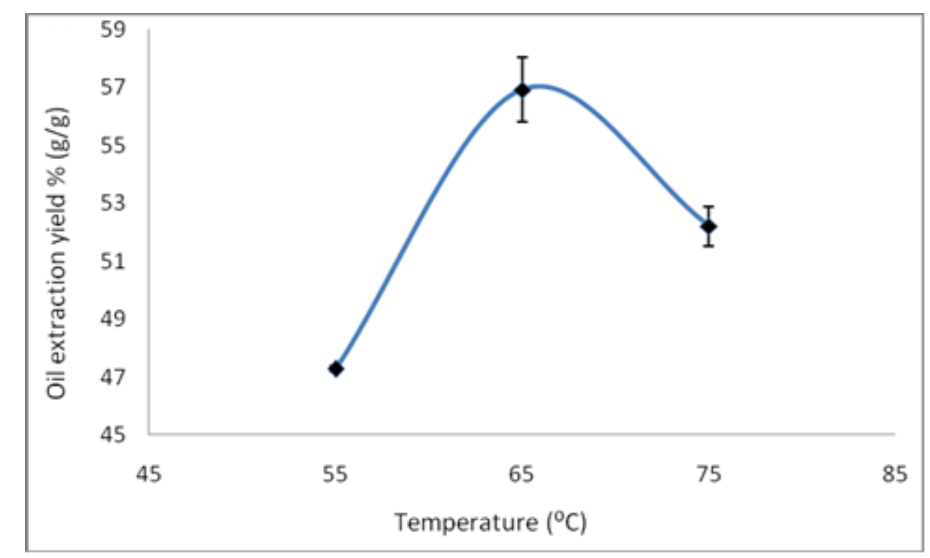

Figure 3. The effect of extraction temperature on the oil extraction yield

At the lower temperature (smaller than $65^{\circ} \mathrm{C}$ ), the oil extraction yield was found to be increased with an increase in the temperature (Figure 2). This result is due to the enhanced in the dissolution capacity of the solvent system [24]. Moderate increase in temperature can lead to a large decrease in fluid density, with a consequent reduction in solute solubility and volatility which resulted in the increase of oil yield [26]. In addition, the increase in temperature will also accelerate the mass transfer and improve the oil extraction yield [27]. However, the result in Figure 3 shows a decrease in oil yield from temperature of 65 to $75^{\circ} \mathrm{C}$. High temperature will affect the solubility of interfering substances in the sample, resulting in lower selectivity of the extracts. Moreover, too high of an extraction temperature may cause partial decomposition of the extracted substances and thus disturb the result of the extracted lipids [28]. From the result obtained in Figure 3, it can be concluded that the maximum oil extraction yield was obtained at temperature of $65{ }^{\circ} \mathrm{C}$ which is $56.92 \%$. This result was also found in the study of the effect of temperature on the extraction yield of spearmint (M. spicata L.) leaves at 3 different temperature level of 40, 50 and $60{ }^{\circ} \mathrm{C}$ [29]. The extraction yield of spearmint leaves increased with temperature and the highest extraction yield $(60.57 \mathrm{mg} / \mathrm{g})$ was obtained at $60{ }^{\circ} \mathrm{C}$.

\section{Effect of extraction time on oil extraction}

In this research, the effect of extraction time on the oil extraction yield of $C$. vulgaris was examined with different time intervals varying from 4 to 8 hours. The result obtained in Figure 4 shows that the oil extraction yield enhanced with the increase of extraction time. The extraction was settled at the optimum mixing rate and temperature from the previous experiment which is $600 \mathrm{rpm}$ and $65{ }^{\circ} \mathrm{C}$, respectively. The oil yield was observed to be increased from $56.09 \%$ to $61.27 \%$ from 4 hours to 6 hours. However, at 8 hours, the oil yield did not show any significant changes in the extraction where $61.26 \%$ of oil can be extracted at that time. Hence, 6 hours was found to be an optimum extraction time for the oil extraction of $C$. vulgaris where the oil obtained is in the maximum yield $(61.27 \%)$.

It is crucial to determine the optimum extraction time required for the extraction process. As the extraction time increases, the oil yield also increases. The increase in the oil yield is due to the increase of mass transfer of oil [24]. However, at 8 hours, the oil yield becomes constant because the extraction has gone completion at 6hours and no 
further increase in oil extraction yield was observed. Thus, it can be concluded that the maximum oil yield was obtained at 6 hours which is $61.27 \%$.

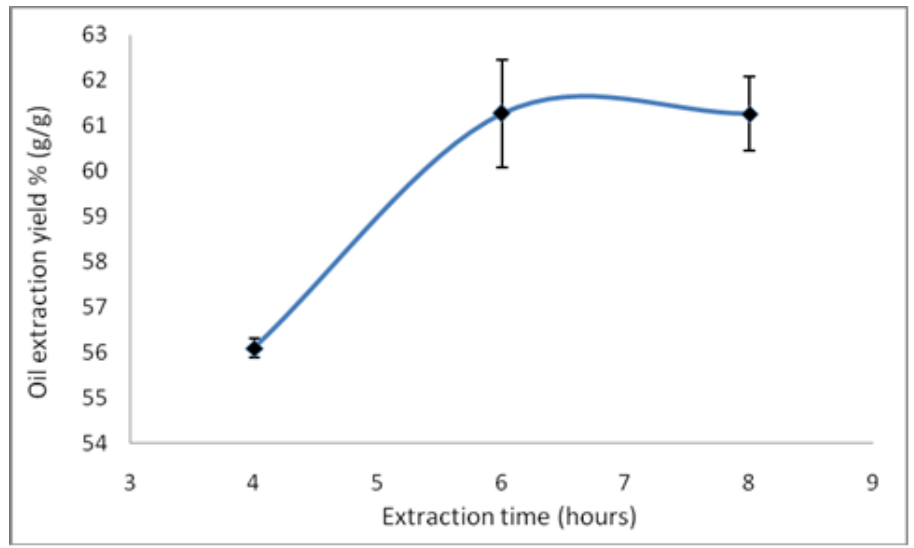

Figure 4. The effect of extraction time on the oil extraction yield

A similar pattern of oil yield produce also was made by McConnel and Farag [30] which studied the extraction of $C$. vulgaris using solvent to dry algae ratio of 30:1 at different time interval varying from 5 to 100 minutes. The optimum time was found to be 60 minutes for maximum production of oil at $2.60 \mathrm{~g}$ lipid extracted per $100 \mathrm{~g}$ of dry algae. At the extraction longer than 60 minutes, the oil yield obtained is constant. Another research by Suganya and Renganathan [24] was studied the effect of extraction time on the oil yield of $U$. lactuca at different time intervals varying from 20 to 160 min shows that at 140 minutes, the oil was found at the maximum yield which is $10.59 \%$ and at extraction time above $140 \mathrm{~min}$ did not show any further significant improvement in the extraction.

\section{Conclusion}

The extraction of oil from Chlorella vulgaris biomass using heptane showed the highest result compared to the other solvent systems with the yield of $57.5 \%$. By using heptane as solvent system, the maximum oil extraction yield of $61.27 \%$ was obtained with optimum conditions of mixing rate of $600 \mathrm{rpm}$, temperature of $65{ }^{\circ} \mathrm{C}$ and 5 hours of extraction time from $C$. vulgaris. The result shows that the oil extraction yield increasing with the increase of mixing rate, temperature and extraction time. When the operating condition of the extraction process passes the optimum condition, the oil yield of $C$. vulgaris show no significant increases. The constant oil yield extracted is because the extraction has gone completion at that point. Extraction process should not be done at higher temperature to avoid the decomposition of the microalgae which will affect the result of oil yield obtained.

\section{Acknowledgement}

The authors would like to acknowledge the UMP Research Grant (Grant No. RDU 140390 and RDU 150396) from Universiti Malaysia Pahang, which has fully supported this research.

\section{References}

1. Hannon, M., Gimpel, J., Tran, M., Rasala, B. and Mayfields, S. (2010). Biofuels from alga: Challenges and potential. Biofuels, 1(5): $763-784$.

2. Demirbas, A. (2009). Production of biodiesel from algae oils. Energy Sources A, 31: $163-168$.

3. Demirbas, A. and Demirbas, F. M. (2011). Importance of algae oil as a source of biodiesel. Energy Conversion and Management, 52: $163-170$.

4. Chisti Y. (2007). Biodiesel from microalgae. Biotechnology Advances, 25: 294 - 306.

5. Islam, M. A., Brown, R. J., O'Hara, I., Kent, M. and Heimann, K. (2014). Effect of temperature and moisture on high pressure lipid/oil extraction from microalgae. Energy Conversion and Management, 88: 307 - 316. 
6. Weingarten, H. (2015). What is expeller and why does it matter. Retrieved from http://blog.fooducate.com/2010/12/08/what-is-expeller-pressed-oil-and-why-does-itmatter/http://biofuel. org.uk /second-generation-biofuels.html. Date access 25 November 2015.

7. Mongkholkhajornsilp, D., Donglas, P. L., Elkamel, A., Tepparitoon, W. and Pongamphair, S. (2004). Supercritical $\mathrm{CO}_{2}$ extraction of nimbim from neem seeds-a modeling study. Journal of Food Engineering, 71(4): $331-340$.

8. Niraj, S. T., Sunita, J. R., Renge, V. C., Satish, V. K., Chavan, Y. P. and Bhagat, S. L. (2011). Extraction of oil from algae by solvent extraction and oil expeller method. International Journal Chemical Science, 9(4): 1746 1750 .

9. Ahmad, A. L., Mat Yasin, N. H., Derek, C. J. C and Lim, J. K. (2013). Microfiltration of Chlorella sp.: Influence of material and membrane pore size. Membrane Water Treatment, 4(2): 143 - 155.

10. Kirolia, A., Bishnoi, N. R. and Singh, R. (2013). Microalgae as a boon for sustainable energy production and its future research and development aspects. Renewable and Sustainable Energy Review, 20: 642 - 656.

11. Mata, T. M., Martins, A. A. and Caetano, N. S. (2010). Microalgae for biodiesel production and other applications: A review. Renewable and Sustainable Energy Review, 14: 217 - 232.

12. Al-Iwayzy, S. H., Yusaf, T. and Al-Juboori, R. A. (2014). Biofuels from the fresh water microalgae Chlorella vulgaris (FWM-CV) for diesel engines. Energies, 7: 1829 - 1851.

13. Ahmad, A. L., Mat Yasin, N. H., Derek, C. J. C and Lim, J. K. (2014). Chemical cleaning of a cross-flow microfiltration membrane fouled by microalgal biomass. Journal of Taiwan Institute of Chemical Engineers, 45: $233-241$.

14. Halim, R., Gladman, B., Danquah, M. K. and Webley, P. A. (2011). Oil extraction from microalgae for biodiesel production. Bioresource Technology, 102: 178 - 185.

15. Ahmad, A. L., Mat Yasin, N. H., Derek, C. J. C and Lim, J. K. (2014). Comparison of harvesting methods for microalgae Chlorella vulgaris sp. and its potential use as a biodiesel feedstock. Environmental Technology, 35(17-20): $2244-2253$.

16. Gutierrez, L. F., Ratti, C. and Belkacemin K. (2008). Effects of drying method on the extraction yields and quality of oils from quebec sea buckhtom (Hipphophaerhamnoides L.) seeds and pulp. Food Chemistry, 106: $896-904$.

17. Rezaie, M., Farhoosh, R., Iranshahi, M., Sharif, A. and Golmohamadzadeh, S. (2015). Ultrasonic- assisted extraction of antioxidative compounds from Bene (Pistacia atlantica subsp. Mutica) hull using various solvents of different physicochemical properties. Food Chemistry, 173: 577 - 583.

18. Reichardt, C. and Welton, T. (2011). Solvents and solvent effects in organic chemistry. John Wiley \& Sons.

19. Wijekon, M., Bhat, R. and Karim, A. A. (2011). Effect of extraction solvents on the phenolic compounds and antioxidant activities of bunga kantan (Etlingera elatior Jack) inflorescence. Journal of Food Composition and Analysis, 24: 615 - 619 .

20. Conkerton, E. J., Wan, P. J. and Richard, O. A. (1995). Hexane and heptane as extraction solvents for cottonseed: A laboratory-scale study. Journal of American Oil Chemical Society, 72: 963 - 965.

21. Ryckebosch, E., Myuylaert, K. and Foubert, I. (2012). Optimisation of an analytical procedure for extraction of oils from microalgae. Journal of American Oil Chemical Society, 89: 189 - 198.

22. Li, Y., Naghdi, F. G., Garg, S., Adarme-Vega, T. C., Thurecht, K. J., Ghafor, W. A., Tannock, S. and Schenk P. M. (2013). A comparative study: the impact of different oil extraction methods on current microalgal oil research. Microbial Cell Factories, 13: 1475 - 2859.

23. Shen, Y., Pei, Z. J., Yuan, W. Q. and Mao, E. R. (2009). Effect of nitrogen and extraction method on algae oil yield. International Journal of Agriculture and Biology Engineering, 2: 51 - 57.

24. Suganya, T. and Renganathan, S. (2012). Optimization and kinetic studies on algae oil extraction from marine macroalgae Ulvalactuca. Bioresources Technology, 107: 319 - 326.

25. Kadi, H. and Fellag, H. (2110). Modeling of oil extraction from olive foot cake using hexane. Grass Aceitas, 52: $369-372$.

26. Roop, R. K., Akgerman, A., Dexter, B. J. and Irvin, T. R. (1989). Extraction of phenol from water with supercritical carbon dioxide. Journal of Supercrital Fluids, 2: $51-56$.

27. Wang, L., Yang, B., Du, X. and Yi, C. (2008). Optimization of supercritical extraction of flavonoids from Puerarialabota. Food Chemistry. 108: 737 - 741. 
Nurfarahanim et al: ALGAE OIL EXTRACTION FROM FRESHWATER MICROALGAE Chlorella vulgaris

28. Fang, Z., Smith, R. L. and Qi, X. H. (2015). Production of biofuels and chemicals with ultrasound. Journal of Food Engineering, 5: 147 - 148.

29. Bimakr, M., Abdul Rahman, R., Taip, F. S., Ganjiloo, A., MdSalleh, L., Selamat, J., Hamid, A. and Zaidul, A. S. M. (2011). Comparison of different extraction methods for the extraction of major bioactive flavonoid compounds from Spearmint (Menthaspicata L.) leaves. Food and Bioprocess, 89: 67 - 72.

30. McConnel, B. and Farag, H. I. (2013). Kinetics study of the solvent extraction of lipids from Chlorella vulgaris. International Journal of Engineering and Technical Research, 10:1-10. 